\title{
ISOLATION OF NEWLY ISOLATED VB_K1 BACTERIOPHAGE AND INVESTIGATION OF SUSCEPTIBILITY ON ESBL POSITIVE KLEBSIELLA SPP. STRAINS
}

\author{
YENI IZOLE EDILEN VB_K1 BAKTERIYYFAJININ IZOLASYONU VE ESBL POZITIFF \\ KLEBSIELLLA TÜRLERİ ÜZERINE DUYARLILIĞININ ARAŞTIRILMASI
}

\author{
Hilal Basak EROL ${ }^{1, *}$ (D), Banu KASKATEPE ${ }^{1}$ \\ ${ }^{1}$ Ankara University, Faculty of Pharmacy, Department of Pharmaceutical Microbiology, 06560, \\ Ankara, Turkey
}

\begin{abstract}
Objective: The decrease in the efficacy of antimicrobials in the treatment of Klebsiella-related infections necessitated the search for alternative treatment strategies. This study aims to provide isolation of lytic bacteriophage specific to Klebsiella species and to investigate its potential for use as alternative antimicrobial agent.

Material and Method: One Extended spectrum beta lactamase (ESBL) producer Klebsiella strain was used as host bacteria and water samples were collected from river in Ankara for bacteriophage isolation. Spot test method was applied to determine the possible presence of bacteriophage after phage enrichment. To confirm the presence of the lytic bacteriophage, double layer agar method was applied to spot test positive samples. The susceptibility of the bacteriophage was determined using in vitro spot test. 38 clinical ESBL positive Klebsiella spp. strains were used for this analysis.

Result and Discussion: In the initial screening, the $v B \_K 1$ bacteriophage producing visible plaques with a diameter of $1.00 \mathrm{~mm}$ was isolated in the petri dish. The susceptibility of ESBL positive Klebsiella spp. strains to this bacteriophage was determined as $73.7 \%$. It was proved that $v B \_K 1$ bacteriophage is very effective to Klebsiella spp. strains. However, in vitro bacteriophage susceptibility of characterized bacteriophage is encouraging development.

Keywords: Bacteriophage, resistance, ESBL, Klebsiella spp.

ÖZ

Amaç: Klebsiella ile ilişkili enfeksiyonların tedavisinde kullanılan antimikrobiyallerin etkinliğindeki azalma, alternatif tedavi strateji arayışlarını gerektirmiştir. Bu çalışma Klebsiella türlerine özgü litik karakterde bakteriyofaj izolasyonunun sağlanmasını ve alternatif antimikrobiyal ajan olarak kullanım potansiyelinin araşstırılmasııı amaçlamaktadır.
\end{abstract}

\footnotetext{
Corresponding Author/Sorumlu Yazar: Hilal Basak Erol

e-mail / e-posta: hcuhadaroglu @ ankara.edu.tr, Phone / Tel: +903122033187
} 
Gereç ve Yöntem: Ankara deresinden alınan su örneklerinden faj izolasyonu için, Genişlemiş spektrumlu beta laktamaz (GSBL) üreticisi bir adet Klebsiella spp. suşu konak bakteri olarak kullanıldi. Faj zenginleştirme sonrası, olası bakteriyofaj varlı̆̆ını belirlemek için spot test yöntemi uygulandı. Litik bakteriyofaj varlı̆̆l, spot testi pozitif numunelere çift tabaka agar yöntemi uygulanarak doğrulandl. Bakteriyofajın duyarlılı̆̆l, $38 \mathrm{klinik}$ GSBL pozitif Klebsiella spp. suşu kullantlarak in vitro spot test ile belirlendi.

Sonuç ve Tartışma: Illk taramada petride $1.00 \mathrm{~mm}$ çapında görünür plaklar üreten $v B \_K 1$ bakteriyofajı izole edildi. GSBL pozitif Klebsiella spp. suşlarının bakteriyofaj duyarlılığ \% $\% 3.7$ olarak belirlendi. vB_K1 bakteriyofajının Klebsiella suşları üzerinde çok etkili olduğu kanıtlanmıştır. Bununla birlikte, karakterize e dilen bakteriyofajin in vitro bakteriyofaj duyarlılı̆̆ cesaret verici bir gelişmedir.

Anahtar Kelimeler: Bakteriyofaj, direnç, ESBL, Klebsiella spp.

\section{INTRODUCTION}

Klebsiella spp. belong to the family Enterobacteriaceae and are found in human microbiota, especially in the gastrointestinal, respiratory tracts and skin. It is an opportunistic pathogen that can cause a wide variety of community-acquired and nosocomial infections, such as urinary tract infections, respiratory tract infections, wound and soft tissue infections [1]. Resistance to antimicrobials is increasing day by day and $\beta$-lactamase production is an important resistance mechanism among them. Pathogens that produce extended-spectrum $\beta$-lactamases (ESBLs) show resistance not only to thirdgeneration cephalosporins and monobactams, but also to other classes of antibiotics [2]. ESBL resistance genes are located on plasmids and therefore are carried and cause significant infections in other strains. This causes an increase in infection control problems [3].

Extended-spectrum $\beta$-lactamase (ESBL) producer Klebsiella spp. are among the six drug-resistant microorganisms for which new therapies are urgently needed. Furthermore, ESBL positive Klebsiella infections cause serious morbidity and mortality in humans, increasing healthcare costs and treatment burden [4]. Alternative or complementary therapies for these infections are required.

Bacteriophages are defined as bacterial viruses and they show specific effects to their specific target bacteria. The existence of bacteriophages first emerged in 1896 when M. Ernest Hankin observed that people washed by the Ganges river waters of India did not contract cholera. Felix d'Herelle named "invisible microbe of the dysentery bacillus" as bacteriophage in 1917 and was the first to announce the antimicrobial effect of bacteriophages to the world [5]. Bacteriophages are defined as bacterial viruses that target and kill their specific bacteria. It was used clinically for the first time in 1919 by Felix D'Herelle in France [6]. Bacteriophages, which were thought to be used as antibacterial material, were used in the treatment of many diseases such as upper respiratory tract infections, abscesses, burns and inflamed wounds in a few countries such as Georgia, Poland, former Russia and the USA until the 1940s. With the discovery of antibiotics in 1941, bacteriophage therapy somehow fell into the background, but in the Soviet line countries (in the early 1990s) while the civil war continued, it continued to be used in the treatment of soldiers against Staphylococcus aureus, Pseudomonas aeruginosa, Escherichia coli and Streptococcus pyogenes bacteria [7]. 
Bacteriophages can be found wherever bacteria are found. Bacteria can be found in almost any environment, such as seawater, fresh water and soil, so bacteriophages can be found anywhere they host [8]. In addition to their therapeutic usage, they can be used in many areas such as disinfection, bacterial identification, determination of subtypes of bacterial strains, in food and livestock conservation [9].

Bacteriophages basically have two life cycles, in some, both life cycles can be seen. Bacteriophages in the lytic life cycle are called virulent (lytic) bacteriophages, while bacteriophages in the lysogenic life cycle are called lysogenic bacteriophages [10]. In the lytic bacteriophages used in the treatment, the target bacteria are broken down and hundreds of phage progeny are released [11]. In the treatment of bacteriophage, it is important that the bacteriophage has a strong lytic effect and has a high host cell specificity [12].

To develop an effective antimicrobial agent, previously studies have been isolated and characterized bacteriophages specific for Klebsiella spp., especially Klebsiella pneumoniae ( $K$. pneumoniae) [13-16]. The objective of this work was to isolate potentially therapeutic bacteriophage against ESBL positive Klebsiella strains. We also determined the in vitro susceptibility of 38 previously characterized ESBL-producing Klebsiella spp. to a newly isolated bacteriophage.

\section{MATERIAL AND METHOD}

\section{Bacteriophage Isolation}

One ESBL producer Klebsiella spp. strain was used as host bacteria and water samples were collected from river in Ankara for bacteriophage isolation. Spot test method was applied to determine the possible presence of bacteriophage after phage enrichment. For this, the water sample was centrifuged and the particles in it were removed, and the supernatant was passed through a $0.22 \mu \mathrm{m}$ membrane filter. Fresh bacteria culture was cultivated in x2 Luria Bertani Broth (Merck) medium enriched with $\mathrm{CaCl}_{2}$ and $\mathrm{MgSO}_{4}$ and incubated at $37^{\circ} \mathrm{C}$ for one night. After incubation, the suspension was centrifuged to remove the cell debris and particles, and bacteria were killed by addition of supernatant to $10 \%$ chloroform. For spot test, a strip of fresh bacterial culture was inoculated into petri dishes containing the medium, and $10 \mu \mathrm{L}$ of the possible bacteriophage suspension obtained was dripped onto these areas. At the end of one-night incubation, the presence of zones in the cultivation areas was evaluated [17].

To confirm the presence of the lytic bacteriophage, a double layer agar method was applied to spot test positive samples. The supernatant was mixed with fresh bacterial culture and soft agar $(0.6 \%$ agar) and spread on agar plate $\left(1.5 \%\right.$ agar). After one-night incubation at $37{ }^{\circ} \mathrm{C}$, the petri dishes were evaluated for the presence of bacteriophage plaques $[18,19]$. 


\section{Single Plaque Isolation}

Single plaque isolation was performed from one of the petri dishes in which bacteriophage plaque was detected. The plaque was cut from the area with a sterile pasteur pipette and transferred to $3 \mathrm{~mL}$ Luria Bertani broth medium. Fresh bacterial culture was added on it $3 \mathrm{~mL}$ more Luria Bertani broth was added on it and incubated at $37{ }^{\circ} \mathrm{C}$. The next day, the bacteriophage suspension was centrifuged at 5000 rpm for 10 minutes and passed through a $0.22 \mu \mathrm{m}$ membrane filter. The double layer agar method was applied to the dilutions of the bacteriophage. This stage will be repeated at least 5 times [20,21].

\section{Preparation of Concentrated Bacteriophage Suspension}

In order to obtain the concentrated bacteriophage suspension, double layer agar was applied to the dilution where the phage and the host achieved the most appropriate growth together. The next day, the soft agar portion was taken with a Drigalski spatula, filtered through $0.22 \mu \mathrm{m}$ membrane filter. The bacteriophage titer was determined as 'plaque forming unit' (PFU) using the double layer agar method by making 10 -fold serial dilutions.

\section{The Susceptibility of Bacteriophage}

The susceptibility of the bacteriophage was determined using in vitro spot test. 38 clinical ESBL positive Klebsiella spp. strains were used for this analysis. All strains were spread evenly on the LB agar plate. After drying, $10 \mu \mathrm{L}$ of the phage culture of $10^{8} \mathrm{PFU} / \mathrm{mL}$ was dropped onto the overlaid top agar. After culturing for $18 \mathrm{~h}$ at $37^{\circ} \mathrm{C}$, the presence or absence of a lysis zone was evaluated [22].

\section{RESULT AND DISCUSSION}

Klebsiella is a clinically important pathogen causing a variety of antibiotic resistant infections. The fact that ESBL-producing $K$. pneumoniae strains even become resistant to carbapenems increases the incidence of infections caused by these strains. As well as the increase in Klebsiella infections in community and hospital settings, there are many studies on bacteriophages, which are seen as an alternative to treatment [23]. There are a number of considerations in the selection of bacteriophages as therapeutic antimicrobial agents. Firstly, the bacteriophages must be effective at killing Klebsiella. Bacteriophages produce large, clear plaques containing large numbers of phage particles, allowing the bacteria to break down rapidly. In addition, bacteriophages with a wide host range are considered to be more beneficial than those with a narrow host range. Second, compared to lysogenic bacteriophages, which integrate their genetic information into the host genome and remain dormant for an indefinite period, lytic bacteriophages clear bacteria quickly and efficiently [24]. This demonstrates the necessity of characterizing bacteriophages before selecting them for therapeutic use.

In our study, one Klebsiella spp. isolate was used to find lytic bacteriophage from the collection of water samples obtained from the river water. Among all, one filtrate produced clear zones against the host 
bacteria was selected. A newly isolated bacteriophage was named vB_K1. The vB_K1 bacteriophage produced visible plaques on the bacterial lawns $1.00 \mathrm{~mm}$ diameter in the initial screening using plaque assay (Figure 1). The susceptibility to vB_K1 bacteriophage was determined on 38 previously described as ESBL- producing Klebsiella spp. isolates. Ten of these were K. pneumoniae. Among the 38 Klebsiella spp. strains 29/38 (73.7\%) were susceptible to vB_K1 bacteriophage, but 9/38 (26.3\%) strains were resistant to $\mathrm{vB} \_\mathrm{K} 1$ bacteriophage. The effect of phage on K. pneumoniae strains were $76.9 \%$. The phage was considered to have high activity against Klebsiella spp.. The results are given in Table 1.

Townsend et al. isolated and characterized 30 Klebsiella bacteriophages, distinct lineages, using multiple water samples from different environments and a number of different Klebsiella spp.. They reported in this study that bacteriophages were included in 5 phylogenetic groups and the broadest spectrum vB_KoM-MeTiny bacteriophage had 79\% lytic activity [25]. In another study, Wintachai et al. reported that KP1801 bacteriophage isolated from hospital wastewater lysed 50\% (10/20) of clinical strains [16]. Similarly, Karumidze et al. reported that one or more of the six phages was capable of efficiently lysing $63 \%$ of Klebsiella strains comprising a collection of 123 clinical isolates from Georgia and the United Kingdom [26].

Karamoddini et al. isolate bacteriophages against Klebsiella spp. and evaluate their efficacy against 72 antibiotic-resistant isolates. At the same time, they reported that the use of bacteriophages in high concentration (over $10^{7} \mathrm{PFU} / \mathrm{mL}$ ) increased the effect [27]. Domingo-Calap et al. characterized two newly isolated $K$. pneumoniae bacteriophages, $\pi \mathrm{VLC} 5$ and $\pi \mathrm{VLC} 6$, from environmental samples as possible therapeutic agents by phenotypic and genomic tests [13]. In another study, Kawa et al. was found that 42 of 101 K. pneumoniae isolates (41.6\%) were susceptible to newly isolate bacteriophage KP34. They also was found that $47.1 \%$ of ESBL $(+)$ and $36 \%$ of ESBL (-) strains were susceptible to KP34 phage [28].

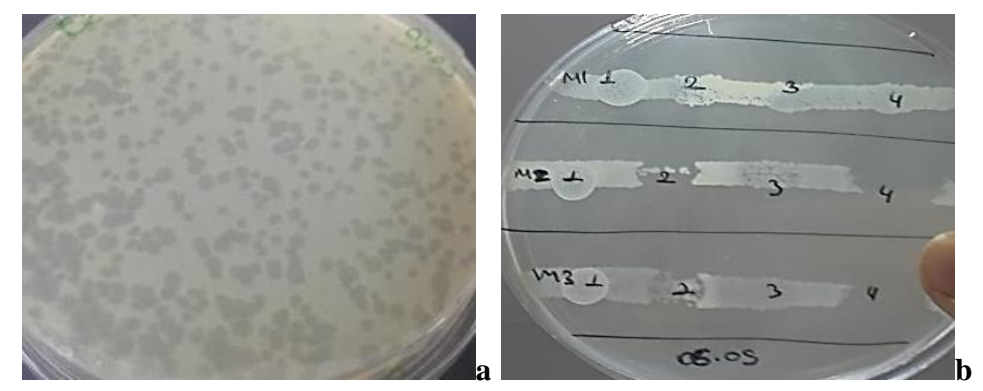

Figure 1. (a) vB_K1 bacteriophage plaque, (b) Spot test results.

Bacteriophage therapy holds promise as a potential response to inhibit the development and spread of MDR Klebsiella species. In vitro and in vivo studies have confirmed the potential use of bacteriophages individually, as bacteriophage cocktails, and in combination with existing antimicrobial chemotherapeutic drugs. In addition, the routine use of bacteriophage therapy in Eastern Europe and the 
results of several clinical studies in the West indicate that bacteriophages are considered safe for use in humans. Eventually, it was proved that isolation and in vitro phage susceptibility results of vB_K1 bacteriophage are promising for Klebsiella species for which there are no ready to use phage preparations, but more detailed characterization studies are needed.

Table 1. Bacteriophage susceptibilities of Klebsiella spp. strains

\begin{tabular}{|c|c|c|c|}
\hline Number & Strain No & & vB_K1 bacteriophage \\
\hline 1 & 384 & ESBL Klebsiella spp. & - \\
\hline 2 & 379 & ESBL K. pneumoniae & +++ \\
\hline 3 & 364 (host) & ESBL Klebsiella spp. & +++ \\
\hline 4 & 285 & ESBL Klebsiella spp. & - \\
\hline 5 & 205 & ESBL Klebsiella spp. & + \\
\hline 6 & 378 & ESBL $K$. pneumoniae & +++ \\
\hline 7 & 382 & ESBL $K$. pneumoniae & - \\
\hline 8 & 240 & ESBL Klebsiella spp. & ++ \\
\hline 9 & 405 & ESBL $K$. pneumoniae & +++ \\
\hline 10 & 206 & ESBL Klebsiella spp. & - \\
\hline 11 & 305 & ESBL Klebsiella spp. & +++ \\
\hline 12 & 333 & ESBL $K$. pneumoniae & + \\
\hline 13 & 166 & ESBL Klebsiella spp. & + \\
\hline 14 & 172 & ESBL Klebsiella spp. & + \\
\hline 15 & 200 & ESBL Klebsiella spp. & - \\
\hline 16 & 434 & ESBL Klebsiella spp. & - \\
\hline 17 & 455 & ESBL Klebsiella spp. & ++ \\
\hline 18 & 338 & ESBL Klebsiella spp. & +++ \\
\hline 19 & 171 & ESBL Klebsiella spp. & ++ \\
\hline 20 & 119 & ESBL Klebsiella spp. & ++ \\
\hline 21 & 82 & ESBL Klebsiella spp. & + \\
\hline 22 & 176 & ESBL Klebsiella spp. & +++ \\
\hline 23 & 227 & ESBL $K$. pneumoniae & +++ \\
\hline 24 & 454 & ESBL Klebsiella spp. & +++ \\
\hline 25 & 305 & ESBL Klebsiella spp. & ++ \\
\hline 26 & 373 & ESBL $K$. pneumoniae & - \\
\hline 27 & 379 & ESBL Klebsiella spp. & +++ \\
\hline 28 & 207 & ESBL $K$. pneumoniae & +++ \\
\hline 29 & 205 & ESBL Klebsiella spp. & + \\
\hline 30 & 378 & ESBL $K$. pneumoniae & +++ \\
\hline 31 & 382 & ESBL $K$. pneumoniae & - \\
\hline 32 & 240 & ESBL Klebsiella spp. & ++ \\
\hline 33 & 405 & ESBL $K$. pneumoniae & +++ \\
\hline 34 & 206 & ESBL Klebsiella spp. & - \\
\hline 35 & 305 & ESBL Klebsiella spp. & +++ \\
\hline 36 & 333 & ESBL $K$. pneumoniae & + \\
\hline 37 & 201 & ESBL K. pneumoniae & +++ \\
\hline 38 & 178 & ESBL Klebsiella spp. & + \\
\hline \multicolumn{3}{|c|}{ Lytic Effect\% } & 73.7 \\
\hline
\end{tabular}

+++: CL (Clear Lysis), ++: SCL (Semi-Clear Lysis), +: OL (Opaque Lysis), -: No lysis [22]. 


\section{AUTHOR CONTRIBUTIONS}

Concept: H.E, B.K.; Design: H.E, B.K.; Supervision: H.E, B.K.; Resources: H.E, B.K.; Materials: H.E, B.K.; Data Collection and/or Processing: H.E, B.K. ; Analysis and/or Interpretation: H.E, B.K.; Literature Search: H.E, B.K.; Writing: H.E, B.K.; Critical Reviews: H.E, B.K.

\section{CONFLICT OF INTEREST}

The authors declare no conflict of interest.

\section{REFERENCES}

1. Podschun, R., Ullmann, U. (1998). Klebsiella spp. as nosocomial pathogens: epidemiology, taxonomy, typing methods, and pathogenicity factors. Clinical Microbiology Reviews, 11(4), 589603. [CrossRef]

2. Moxon, C. A., Paulus, S. (2016). Beta-lactamases in Enterobacteriaceae infections in children. Journal of Infection, 72 Suppl, S41-49. [CrossRef]

3. Bitsori, M., Galanakis, E. (2019). Treatment of urinary tract infections caused by ESBL-producing Escherichia coli or Klebsiella pneumoniae. The Pediatric Infectious Disease Journal, 38(12), e332e335. [CrossRef]

4. Peleg, A. Y., Hooper, D. C. (2010). Hospital-acquired infections due to gram-negative bacteria. New England Journal of Medicine, 362(19), 1804-1813. [CrossRef]

5. Golkar, Z., Bagasra, O., Pace, D. G. (2014). Bacteriophage therapy: a potential solution for the antibiotic resistance crisis. The Journal of Infection in Developing Countries, 8(2), 129-136. [CrossRef]

6. Chanishvili, N. (2012). A literature review of the practical application of bacteriophage research. New York: Nova Biomedical Books.

7. Bruttin, A., Brüssow, H. (2005). Human volunteers receiving Escherichia coli phage T4 orally: a safety test of phage therapy. Antimicrobial Agents and Chemotherapy, 49(7), 2874-2878. [CrossRef]

8. Domingo-Calap, P., Delgado-Martinez, J. (2018). Bacteriophages: protagonists of a post-antibiotic era. Antibiotics (Basel), 7(3), 1-16. [CrossRef]

9. Kazi, M., Annapure, U. S. (2016). Bacteriophage biocontrol of foodborne pathogens. Journal of Food Science and Technology, 53(3), 1355-1362. [CrossRef]

10. Guttman, B., Raya, R., Kutter, E. (2005). Basic phage biology. Bacteriophages: Biology and applications, 4. 
11. Harper, D. R., Parracho, H. M. R. T., Walker, J., Sharp, R., Hughes, G., Werthén, M., Morales, S. (2014). Bacteriophages and biofilms. Antibiotics, 3(3), 270-284. [CrossRef]

12. Kochetkova, V. A., Mamontov, A. S., Moskovtseva, R. L., Erastova, E. I., Trofimov, E. I., Popov, M. I., Dzhubalieva, S. K. (1989). Phagotherapy of postoperative suppurative-inflammatory complications in patients with neoplasms. Sovetskaia Meditsina, (6), 23-26.

13. Domingo-Calap, P., Beamud, B., Mora-Quilis, L., González-Candelas, F., Sanjuán, R. (2020). Isolation and characterization of two Klebsiella pneumoniae phages encoding divergent depolymerases. International Journal of Molecular Sciences, 21(9), 3160. [CrossRef]

14. Karamoddini, M. K., Fazli-Bazzaz, B. S., Emamipour, F., Ghannad, M. S., Jahanshahi, A. R., Saed, N., \& Sahebkar, A. (2011a). Antibacterial efficacy of lytic bacteriophages against antibioticresistant Klebsiella species. The Scientific World Journal, 11, 370161. [CrossRef]

15. Kumari, S., Harjai, K., Chhibber, S. (2011). Bacteriophage versus antimicrobial agents for the treatment of murine burn wound infection caused by Klebsiella pneumoniae B5055. Journal of Medical Microbiology, 60(Pt 2), 205-210. [CrossRef]

16. Wintachai, P., Naknaen, A., Thammaphet, J., Pomwised, R., Phaonakrop, N., Roytrakul, S., Smith, D. R. (2020). Characterization of extended-spectrum- $\beta$-lactamase producing Klebsiella pneumoniae phage KP1801 and evaluation of therapeutic efficacy in vitro and in vivo. Scientific Reports, 10(1), 11803. [CrossRef]

17. Adams, M. H. (1959). Bacteriophages: Interscience publishers.

18. Merabishvili, M., Pirnay, J.-P., Verbeken, G., Chanishvili, N., Tediashvili, M., Lashkhi, N., Vaneechoutte, M. (2009). Quality-controlled small-scale production of a well-defined bacteriophage cocktail for use in human clinical trials. PLoS One, 4(3), e4944-e4944. [CrossRef]

19. Oliveira, H., Pinto, G., Oliveira, A., Oliveira, C., Faustino, M. A., Briers, Y., Azeredo, J. (2016). Characterization and genome sequencing of a Citrobacter freundii phage CfP1 harboring a lysin active against multidrug-resistant isolates. Applied Microbiology and Biotechnology, 100(24), 10543-10553. [CrossRef]

20. Sambrook, J., Fritsch, E. F., Maniatis, T. (1989). Molecular cloning: a laboratory manual: Cold spring harbor laboratory press.

21. Sasikala, D., Srinivasan, P. (2016). Characterization of potential lytic bacteriophage against Vibrio alginolyticus and its therapeutic implications on biofilm dispersal. Microbial Pathogenesis, 101, 2435. [CrossRef]

22. Knezevic, P., Kostanjsek, R., Obreht, D., Petrovic, O. (2009). Isolation of Pseudomonas aeruginosa specific phages with broad activity spectra. Current Microbiology, 59(2), 173. [CrossRef]

23. Herridge, W. P., Shibu, P., O'Shea, J., Brook, T. C., Hoyles, L. (2020). Bacteriophages of Klebsiella spp., their diversity and potential therapeutic uses. Journal of Medical Microbiology, 69(2), 176194. [CrossRef]

24. Harper, D. R. (2018). Criteria for selecting suitable infectious diseases for phage therapy. Viruses, 10(4), 177. [CrossRef] 
25. Townsend, E. M., Kelly, L., Gannon, L., Muscatt, G., Dunstan, R., Michniewski, S., Jameson, E. (2021). Isolation and characterization of Klebsiella phages for phage therapy. Phage (New Rochelle), 2(1), 26-42. [CrossRef]

26. Karumidze, N., Kusradze, I., Rigvava, S., Goderdzishvili, M., Rajakumar, K., Alavidze, Z. (2013). Isolation and characterisation of lytic bacteriophages of Klebsiella pneumoniae and Klebsiella oxytoca. Current Microbiology, 66(3), 251-258. [CrossRef]

27. Karamoddini, M. K., Fazli-Bazzaz, B. S., Emamipour, F., Ghannad, M. S., Jahanshahi, A. R., Saed, N., Sahebkar, A. (2011b). Antibacterial efficacy of lytic bacteriophages against antibiotic-resistant Klebsiella species. The Scientific World Journal, 11, 1332-1340. [CrossRef]

28. Drulis-Kawa, Z., Mackiewicz, P., Kęsik-Szeloch, A., Maciaszczyk-Dziubinska, E., WeberDąbrowska, B., Dorotkiewicz-Jach, A., Kropinski, A. M. (2011). Isolation and characterisation of KP34-a novel $\varphi \mathrm{KMV}$-like bacteriophage for Klebsiella pneumoniae. Applied Microbiology and Biotechnology, 90(4), 1333-1345. [CrossRef] 